\section{EXCISE TAX \\ ON DAILY \\ FANTASY SPORTS}

MARCIA S. WAGNER AND BARRY L. SALKIN

Marcia S. Wagner, Esq., is the founder and managing partner at Wagner Law Group in Boston, Massachusetts.

Barry L. Salkin, Esq., is of counsel to Wagner Law Group in New York, New York.

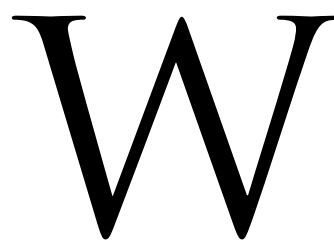

hile the primary purpose of imposing taxes under the Internal Revenue Code is to raise revenue, there are other taxestechnically known as excise taxes, but colloquially referred to as sin taxes - which have as a goal providing a disincentive to certain types of behavior. There are a series of such excise taxes hidden in the back of the Code, and some of those excise taxes are of long duration. For example, Section 3285 of the Internal Revenue Code of 1939, entitled "Wagering Taxes," imposed a $10 \%$ excise tax on the amount of any wagers. Section 3285(b) of the 1939 Code defined the term wager as "any wager with respect to a sports event or a contest placed with a person engaged in the business of accepting such wagers; any wager placed in a wagering pool with respect to a sports event or a contest, if such pool is conducted for profit and (C) any wager placed in a lottery conducted for profit." When the 1939 Code was succeeded by the 1954 Internal Revenue Code, that structure continued. Over time, the wages of sin may remain unchanged, but at least the costs of sin have been reduced, so that the excise tax on wagers has declined significantly, even in states in which the transaction is unlawful. But unfortunately the draftspersons did not realize that the definitions were at best unhelpful, and in fact circular, so Section 4421 under the current Code retains the same definitions as the 1939 Code. As a result, despite "the dissipation in recent times of the historical moral opposition to gambling," and the suggestions that Congress should consider updating the law, the task for the Internal Revenue Service (IRS) or a court is to interpret the existing language. ${ }^{1}$

While there are various rules of statutory construction to define a term that is undefined, the predominant one is probably the plain meaning rule, which was the rule relied upon by the Tax Court in Tschetschot. ${ }^{2}$ Generally, a starting point for determining the plain meaning of a word is the dictionary definition of the term, and a typical starting point, although not the choice made by the Tax Court, would be Black's Law Dictionary. Black's defines a wager as "a contract by which two or more parties agree that a certain sum of money or other thing shall be paid or delivered to one of them or that they shall gain or lose on the happening of an uncertain event or upon the ascertainment of a fact in dispute, where the parties have no interest in the event"; interest in this context meaning something other than a fan's interest in the outcome of a particular sporting event or events. In Tschetschot, the Tax Court stated that:

According to the dictionary, a "wager" is defined as "something risked or staked on an uncertain event" or "a bet," Random House College Dictionary (1968). Similarly, "to wager" is defined as: (1) Something risked or staked on an uncertain event; a bet (2) the act of betting. Random House College Dictionary (1973).

The IRS has also stated that "wagering activities consist of the following three (3) elements: (1) a consideration; (2) an element of chance; and (3) a reward."3 Applying that definition, it was not difficult for the IRS to conclude that daily fantasy sports (DFS) was a wager, and the remainder of the ruling was relatively straightforward, with the IRS responding to likely challenges to its interpretation, as described more fully below. ${ }^{4}$

Is a dictionary definition the best way to determine the plain meaning of a statute? Not necessarily. As a former editor of the Oxford English Dictionary
Keywords: DFS, wager, excise, dictionary

DOI: $10.1089 /$ glr2.2020.29004.mwa (C) 2020 Mary Ann Liebert, Inc.

${ }^{1}$ Under I.R.C. $\S 4401(\mathrm{a})$, the rate is $0.25 \%$ on state authorized wagers and $2 \%$ on unauthorized wagers.
${ }^{2}$ Tschetschot v. Comm'r, T.C. Memo. 2007-38 (U.S. Tax Ct. 2007)

${ }^{3}$ FSA 917 (undated)

${ }^{4}$ Edgewood American Legion Post No. 448 v. United States, 246 F.2d 1 (7th Cir. 1957); Field Service Advice 917 (undated) (collecting cases). 
has observed, "It is probably wrong in almost all instances to use a dictionary in the courtroom. Dictionary definitions are written with a lot of things in mind, but rigorously circumscribing the exact meanings and connotations of terms is usually not one of them." While courts may refer to dictionaries to help elucidate the common understanding of terms, they have also recognized that dictionary definitions are not controlling. ${ }^{6}$ Benjamin Cardozo, Louis Brandeis, and Oliver Wendell Holmes are generally regarded as three of the great jurists of the twentieth century, and the combined number of opinions for those three jurists in which a dictionary was used to decide a case is zero. Another eminent twentieth century jurist, Learned Hand, famously stated in Cabell v. Mark$\mathrm{ham}^{7}$ that "it is one of the surest indices of a mature and developed jurisprudence not to make a fortress out of the dictionary, but to remember that statutes always have some purpose or object to accomplish, whose sympathetic and imaginative discovery is the surest guide to their meaning." Rather than ceasing the inquiry with the dictionary definition, a court, if this matter were ultimately to be litigated, might ask whether it serves the purpose of Code Section 4401 to impose an excise tax on DFS.

A court might well come to the same conclusion as the IRS and the Tax Court, but the language of a statute need not be divorced from its purpose, and, as previously stated, it is worth noting that there are concerns about reliance upon dictionary definitions. As the Tax Court noted in a dissenting opinion in Armstrong, ${ }^{8}$ not all dictionaries are the same. For example, Websters Third New International Dictionary is widely regarded as a descriptive dictionary — one that describes various word usages without prescribing any. In contrast, the American Heritage Dictionary is prescriptive - the proper use of the word. One approach may not be preferable to the other, but there are different approaches. ${ }^{9}$
The IRS Generic Legal Advice Memorandum ${ }^{10}$ and Chief Counsel Advice ${ }^{11}$ also respond to what the IRS believes are likely challenges to its position, two of which are relevant to issues of statutory interpretation. First, the IRS discussed the Unlawful Internet Gambling Enforcement Act of 2006 (UIGEA), an act which generally prohibits gambling businesses from knowingly accepting payments in connection with the participation of another person in a bet or wager that involves the use of the internet and that is unlawful under any state or federal law. The UIGEA defines the term wager to include risking something of value on the outcome of a sporting event, but it also has a carve-out for fantasy sports games. ${ }^{12}$ As a technical matter, the UIGEA appears in a separate section of the United States Code, and the interpretation of a term in one statute does not necessarily have the same meaning in another statute. However, a court might find it instructive that in 2006, Congress excluded certain types of fantasy sports transactions from the definition of wager, because that is arguably an indication that Congress believed that DFS fell within the four corners of the definition of wager. Therefore, it might be argued that the UIGEA indicated there was a difference between the literal meaning of wager, and what the average person might regard as a wager. The IRS sought to minimize this point by commenting in the Generic Legal Advice Memorandum that the "UIGEA was enacted in 2006, prior to the proliferation of DFS, and referred to traditional daily sports," but the IRS's response did not make clear why it thought that it would therefore be inappropriate to apply the language of the 2006 statute to DFS transactions.

As the Supreme Court indicated last term in Bostock v. Clayton County, ${ }^{13}$ even if Congress never envisioned the possibility of statutory language applying to a specific situation, the statutory language could apply to that situation, and it could hardly be said
${ }^{5}$ Quoted by Adam Liptak, "Justices Turning More Frequently to Dictionaries, and Not Just for Big Words," New York Times, June 13, 2011, cited in John C. Calhoun, "Measuring the Fortress: Explaining Trends in Supreme Court and Circuit Court Dictionary Usage," 124 Yale Law Journal 24 (2014).

${ }^{6}$ Martinez v. Sun Life Assurance Company of Canada, 948 F. 3d 62 (1st Cir. 2020).

${ }^{7} 148$ F. 2d 737 (2d Cir. 1945).

${ }^{8}$ Armstrong v. Comm'r, 139 T.C. 468, n.11 (U.S. Tax Ct. 2012).

${ }^{9}$ See Philip A. Rubin, War of The Words: How Courts Can Use Dictionaries in Accordance with Textualist Principles, 60 Duke L.J. 167, 183-184 (2010)

\footnotetext{
${ }^{10}$ I.R.S. Memo. AM 2020-009 (Aug. 7, 2020). A Generic Legal Advice Memorandum may not be used or cited as precedent.

${ }^{11}$ I.R.S. Memo. 202042015 (Oct. 26, 2020).

${ }^{12}$ If the game or contest involves a team or teams, for the carve-out to be available no fantasy sports team may be based on the current membership of an actual team that is a member of an actual or professional sports organization, and certain conditions designed to protect the integrity of the sporting events must be satisfied.

${ }^{13} 140$ S. Ct. 1731 (2020).
} 
that in 2006 the proliferation of DFS activity was totally unforeseeable.

With respect to other challenges to its interpretation of the Code's excise tax on wagering, the characterization by several states of DFS as a game of skill was not relevant, because whether DFS is a game of skill for state gambling purposes is not relevant for purposes of determining whether DFS is wagering for federal excise tax purposes. Further, while the IRS did not question the level of skill required to participate in DFS, Code Sections 4401 and 4421 do not differentiate whether an activity involves skill, chance, or some combination of the two. However, it will be difficult to refute the IRS's contention that there is an element of chance involved in DFS.

Regardless of how educated a DFS participant is, their chosen player(s) may perform poorly that day, become injured, not play in a given game, or be affected by uncontrollable circumstances such as weather and officiating ... We conclude that the "skill" involved in selecting fantasy players is similar to the skill involved in selecting winners of individual professional sports games, horse races, or other traditional sports gambling activities. ${ }^{14}$

One other concern should be noted. To the extent that an entity pays the two percent excise tax for wagers in states in which the transaction is illegal, the entities will be acknowledging their participation in activities that are illegal at the state level.

These two IRS documents are likely to be the opening salvos in what promises to be a lengthy legal struggle to ultimately convince a court that the IRS analysis is flawed. 